\title{
TOPOGRAPHICAL DISTRIBUTION OF DECREMENTS AND RECOVERY IN MUSCARINIC RECEPTORS FROM RAT BRAINS REPEATEDLY EXPOSED TO SUBLETHAL DOSES OF SOMAN ${ }^{1}$
}

\author{
LYNN CHURCHILL, ${ }^{2}$ THOMAS L. PAZDERNIK, JEFFREY L. JACKSON, STANLEY R. NELSON, \\ FRED E. SAMSON, AND JOHN H. MCDONOUGH, JR.*
}

\begin{abstract}
Departments of Anatomy, Pharmacology, Toxicology, and Therapeutics and Ralph L. Smith Research Center, University of Kansas School of Medicine, Kansas City, Kansas 66103 and ${ }^{*}$ United States Army Medical Research Institute for Chemical
\end{abstract} Defense, Aberdeen Proving Ground, Maryland 21010

Received October 27, 1983; Revised February 9, 1984; Accepted March 8, 1984

\begin{abstract}
$\left[{ }^{3} \mathrm{H}\right]$ Quinuclidinyl benzilate binding to rat brain muscarinic receptors decreased after repeated exposure to soman, a potent organophosphorus cholinesterase inhibitor. The topographical distribution of this decrement was analyzed by quantitative receptor autoradiography. After 4 weeks of soman, three times a week, quinuclidinyl benzilate binding decreased to 67 to $80 \%$ of control in frontal and parietal cortex, caudate-putamen, lateral septum, hippocampal body, dentate gyrus, superior colliculus, nucleus of the fifth nerve, and central grey. Minor or no decreases were observed in thalamic or hypothalamic nuclei, reticular formation, pontine nuclei, inferior colliculus, nucleus of the seventh nerve, and cerebellum. Scatchard analyses of saturation curves using frontal cortex sections from soman-treated rats revealed a decrease in maximal quinuclidinyl benzilate binding from that in control rats and a return toward control levels by 24 days without any significant change in affinity. These brain areas showing significant decrements in muscarinic receptors recovered with a similar time course. An estimate of the time for $50 \%$ recovery for some of the brain areas was 14 days for superior colliculus, 16 days for cortex, and 19 days for hippocampal body. The application of quantitative receptor autoradiography to analyze receptor alterations has been valuable in localizing the telencephalon as a region more susceptible to change in receptor concentration.
\end{abstract}

Soman (0,1,2,2-trimethylpropyl methylphosphonofluoridate) is a potent irreversible inhibitor of cholinesterase which has pronounced central actions. Single, near-lethal doses of soman in rats induced intense generalized convulsions and a marked activation of the brain as assessed by 2-deoxyglucose utilization (McDonough et al., 1983a). These effects have been attributed to a rapid accumulation of excess acetylcholine in brain (Michaelis et al., 1954; Fonnum and Gottormsen, 1969; Milosevic, 1970; Shih, 1982), which resulted in excessive cholinergic stimulation at central synaptic sites. Numerous studies have documented that repeated exposure to sublethal doses of

\footnotetext{
${ }^{1}$ The experiments reported here were conducted according to the Guide for Care and Use of Laboratory Animals (1978) as prepared by the Committee on Care and Use of Laboratory Animals, National Research Council, Department of Health, Education and Welfare Publication No. (NIH) 80-23. The opinions and assertions contained herein are our private views and are not to be construed as reflecting the views of the Department of the Army or the Department of Defense. This research was supported by United States Army Grant DAMAD 17-78C-8039. We thank Calvin Beck, Jerry Jackson, and Renee Alverez for their technical assistance and Klaus Mewes for the design and construction of the interface between the microcomputer and densitometer.

${ }^{2}$ To whom correspondence should be addressed, at the Ralph $\mathrm{L}$. Smith Research Center, University of Kansas Medical Center, Kansas City, KS 66103.
}

cholinesterase inhibitors produces a decrease in the concentration of muscarinic receptors (Ehlert and Kokka, 1.977; Schiller, 1979; Uchida et al., 1979; Ehlert et al., 1980a, b; Schwab et al., 1981; Costa et al., 1981, 1982; Yamada et al., 1983). Adaptive changes, such as down-regulation of muscarinic receptors, occur as a consequence of persistent cholinomimetic activity. The overall effect of repeated exposure to these agents is dependent on the cumulative effect on cholinesterase levels and the ability to adapt to these low cholinesterase levels.

Computer-assisted quantitative autoradiography is a valuable tool for determining both the neuroanatomical localization and concentration of receptors in specific brain regions (Biegon et al., 1982; Rainbow et al., 1982; Unnerstall et al., 1982). Alterations in receptor concentration have been analyzed for specific brain regions using this technique on brains from lesioned animals (Palacios and Kuhar, 1981; Penney et al., 1981; Pan et al., 1983). $\left[{ }^{3} \mathrm{H}\right]$ Quinuclidinyl benzilate (QNB) and $\left[{ }^{3} \mathrm{H}\right]$ propylbenzilylcholine mustard binding have been previously used for autoradiographic localization of muscarinic receptors in rat brain (Kuhar and Yamamura, 1975; Rotter et al., 1979). Using $\left[{ }^{3} \mathrm{H}\right] \mathrm{QNB}$, we (Churchill et al., 1984) have shown that muscarinic receptor autoradiography is effective for quantitating the topographical distribution of decrements in muscarinic receptors after repeated exposure to diisopropyl fluorophosphate (DFP). The purpose of this study was to use quantitative receptor autoradiography to analyze the effects of repeated exposure to a potent, central-acting organophosphate 
(soman) on muscarinic receptors and to ascertain whether the effects of soman are transient or long-term.

\section{Materials and Methods}

Albino Sprague-Dawley rats (230 to $260 \mathrm{gm}$ initially) were maintained on a 12-hr light cycle and housed individually. Rats were injected subcutaneously with 60 to $45 \mu \mathrm{g} / \mathrm{kg}$ of soman in saline three times per week for 4 weeks. Controls were injected with saline alone. Rats were injected with $60 \mu \mathrm{g} / \mathrm{kg}$ for the first four injections, $50 \mu \mathrm{g} / \mathrm{kg}$ for the next five, and $45 \mu \mathrm{g} / \mathrm{kg}$ for the last two injections. This decrease in soman exposure was necessary to reduce the death rate, which was $38 \%$ for this regimen (McDonough et al., 1983b).

Rats were perfused with $0.1 \%$ formalin in $0.05 \mathrm{M}$ phosphate-buffered saline, $\mathrm{pH} 7.4$, and decapitated at indicated times after the last injection. Subsequently, brains were removed, quickly frozen by slow immersion in freon, and stored at $-70^{\circ} \mathrm{C}$. Prior to sectioning, brains were equilibrated at $-18^{\circ} \mathrm{C}$ in a cryostat (American Optical, Buffalo, NY) and were then attached to a chuck at a standard angle relative to the cutting blade. Twenty-micrometer coronal sections were cut at about 200- $\mu \mathrm{m}$ intervals. Control and experimental sections were carefully matched to improve comparisons. Sections were thaw-mounted on acidcleaned, subbed microscope slides. The slides were coated with gelatin $(0.5 \%)$ and potassium chromium sulfate $(0.05 \%)$. Sections were stored at $-10^{\circ} \mathrm{C}$ for at least $24 \mathrm{hr}$ and less than 2 weeks.

$\left[{ }^{3} H\right] Q N B$ binding to muscarinic receptors. For topographical localization, muscarinic receptors were labeled using experimental conditions previously described by Wamsley et al. (1981). Experimental and control brain sections were simultaneously incubated in $1 \mathrm{nM}\left[{ }^{3} \mathrm{H}\right] \mathrm{QNB}$ (1-quinuclidinyl [phenyl- $4-{ }^{3} \mathrm{H}$ ] benzilate; 30 to $40 \mathrm{Ci} / \mathrm{mmol}$; Amersham Searle, Arlington Heights, IL) in phosphate-buffered saline for $2 \mathrm{hr}$ at room temperature followed by two 5 -min rinses; for saturation curves, the concentrations ranged from 0.125 to $2 \mathrm{nM}\left[{ }^{3} \mathrm{H}\right] \mathrm{QNB}$. Nonspecific binding was determined by incubation in the presence of $10^{-6} \mathrm{M}$ atropine. After drying, sections were stored on tritium-sensitive film (LKB Ultrofilm, Gaithersburg, MD) for 5 days at room temperature. Film was developed in D-19 (Kodak, Rochester, NY) for 2 min and fixed with Kodak fixer (2 to $4 \mathrm{~min}$ ). $\left[{ }^{3} \mathrm{H}\right] \mathrm{QNB}$ binding to dissected frontal cortex was measured by a filtration assay (Yamamura and Snyder, 1974).

Photography and quantitation of autoradiograms. Autoradiograms on tritium-sensitive film were photographed by exposing $x$-ray film underneath the autoradiogram of both experimental and control sections to light flashes of $0.2 \mathrm{sec}$ and developing these negatives in D-19 (Kodak) for $2 \mathrm{~min}$. The negatives were fixed in Rapid Fixer (Kodak) for $4 \mathrm{~min}$ and printed with a Beseler enlarger using Ektamatic SC paper (Kodak) developed with an Ektamatic processor (Kodak). The exposure time was standardized for both control and experimental brain sections.

Matched brain sections were selected from the autoradiogram for quantitation, which was completed by measuring the film density using a light-sensitive pen with a $0.25-\mathrm{mm}$ aperture. The light pen was attached to a model TBX densitometer (Tobias Associates, Ivyland, PA), and an Aristo grid larger was used as a uniform light source. The densitometer was interfaced with a Radio Shack TRS 80 model 1 microcomputer which summated and averaged the film density readings over a brain region. The densitometer was zeroed in the background near each section, since nonspecific binding with $10^{-6} \mathrm{M}$ atropine did not expose the film above background. A constant number of readings was taken for each brain structure. For large areas, 10 to 20 readings were taken over a wide surface; for small areas 5 to 10 readings were taken. Readings were averaged over three to four sections within each brain and over three to six different brains with similar treatments. Statistical analyses of differences between soman-treated rats at $24 \mathrm{hr}$ after the last injection and controls were conducted utilizing a Student's $t$ test. When statistically analyzing the recovery of receptors, analysis of variance was conducted on the film density data, and the Dunnett's test was used to test significance. Significance was inferred when $p<$ 0.05 . The results were expressed as percentage of control, and the standurd error of each percentage was calculated as:

$$
\mathrm{SE} \%=\frac{100}{\bar{y}} \cdot \sqrt{\frac{\operatorname{var}(\bar{x})}{n_{1}}+\frac{\bar{x}^{2}}{\bar{y}^{2}} \cdot \frac{\operatorname{var}(\bar{y})}{n_{2}}}
$$

where $\bar{x}$ and $\bar{y}$ were the mean values in soman-treated and control groups and $n_{1}$ and $n_{2}$ represented the number of rats in each group (Davies, 1961).
Standardization of the film density measurements was achieved by measuring the relationship between film densities and radioactivity bound to the sections. Frontal coronal sections were incubated in a range of $\left[{ }^{3} \mathrm{H}\right] \mathrm{QNB}$ concentrations $(0.125$ to $2.0 \mathrm{nM})$, and the frontal cortex area within each section was quantitated by both autoradiography and scintillation counting. The area of frontal cortex analyzed was from cingulate cortex to rhinal fissure. A template was constructed so that equivalent areas were scraped and quantitated by densitometry. Scrapings of cortex $(0.05$ to $0.1 \mathrm{mg})$ were weighed on an Electrocahn balance and placed in 3a70 scintillation fluid (Research Products International Corp., Prospect, IL) overnight prior to counting. The protein content of scraped frontal cortex was measured using the method of Lowry et al. (1951) with bovine serum albumin as the standard. For densitometric measurements, the light-sensitive pen $(0.25-\mathrm{mm}$ aperture) was placed on adjacent points along the area marked off by the template (usually 48 points/section). $\left[{ }^{14} \mathrm{C}\right]$ Methyl methacrylate standards (Amersham) were placed on the same sheets with the slide-mounted tissue sections, and their densities were measured to compensate for differences between autoradiograms due to film exposure and development.

\section{Results}

Quantitation of QNB binding by muscarinic receptor autoradiography. The autoradiogram density for the frontal cortex previously incubated in a range of QNB concentrations and the radioactivity in frontal cortex scraped from the same sections were quantified and compared. For the narrow range of film densities and radioactivities calculated with these QNB concentrations, an approximate linear relationship was found between the picomoles of QNB bound per milligram of tissue and the film density after a 5-day film exposure (Fig. 1). Utilizing this standard relationship (0.484 density units/pmol of QNB/ $\mathrm{mg}$ of tissue), the saturation curve for $\left[{ }^{3} \mathrm{H}\right] \mathrm{QNB}$ binding to frontal cortex was converted from film density to picomoles of QNB per milligram of tissue. The saturation curve for $\left[{ }^{3} \mathrm{H}\right]$ QNB binding to frontal cortices of rat brain sections is shown in Figure 2. Scatchard analyses of this data were linear with a correlation coefficient of 0.86 and revealed a $B_{\max }$ of $1.10 \mathrm{pmol} /$ $\mathrm{mg}$ of tissue and $K_{D}$ of $0.89 \mathrm{nM}$ (Fig. 2, inset).

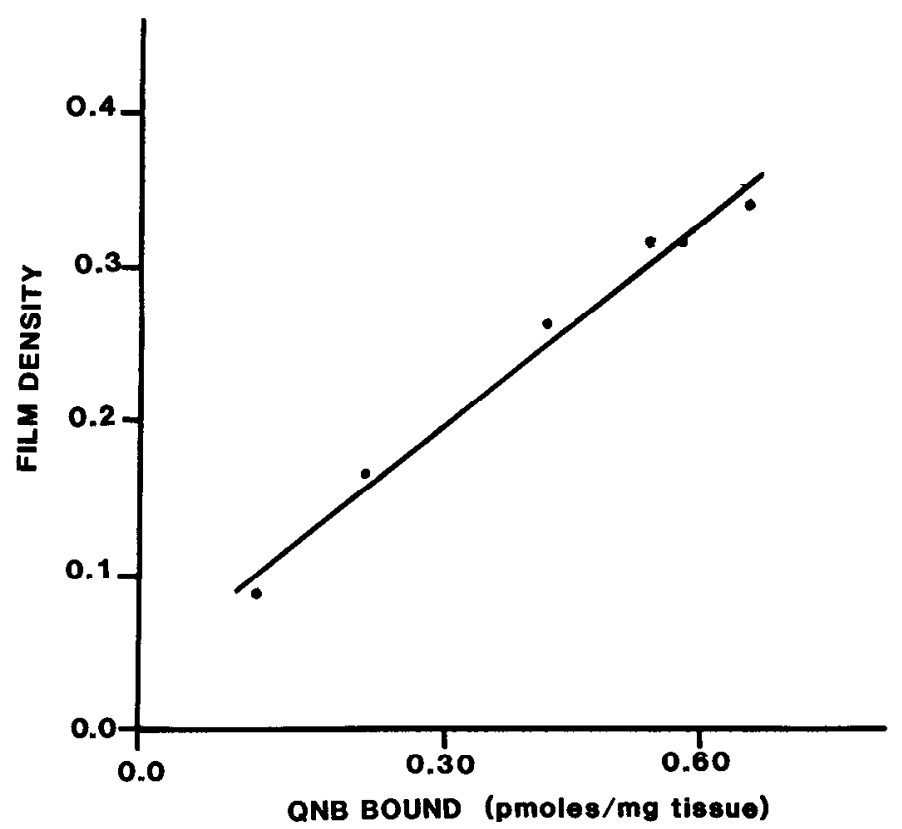

Figure 1. Relationship between radioactivity bound to muscarinic receptors in frontal cortex sections and film density of the same brain section attained from ${ }^{3} \mathrm{H}$-sensitive film. In this narrow range of film density and radioactivity, a constant relationship exists between average film density after 5 days of exposure and $\left[{ }^{3} \mathrm{H}\right] \mathrm{QNB}$ bound per milligram of tissue after scraping and counting these sections. This plot is linear with a correlation coefficient of 0.99 . This figure represents data from three experiments. 


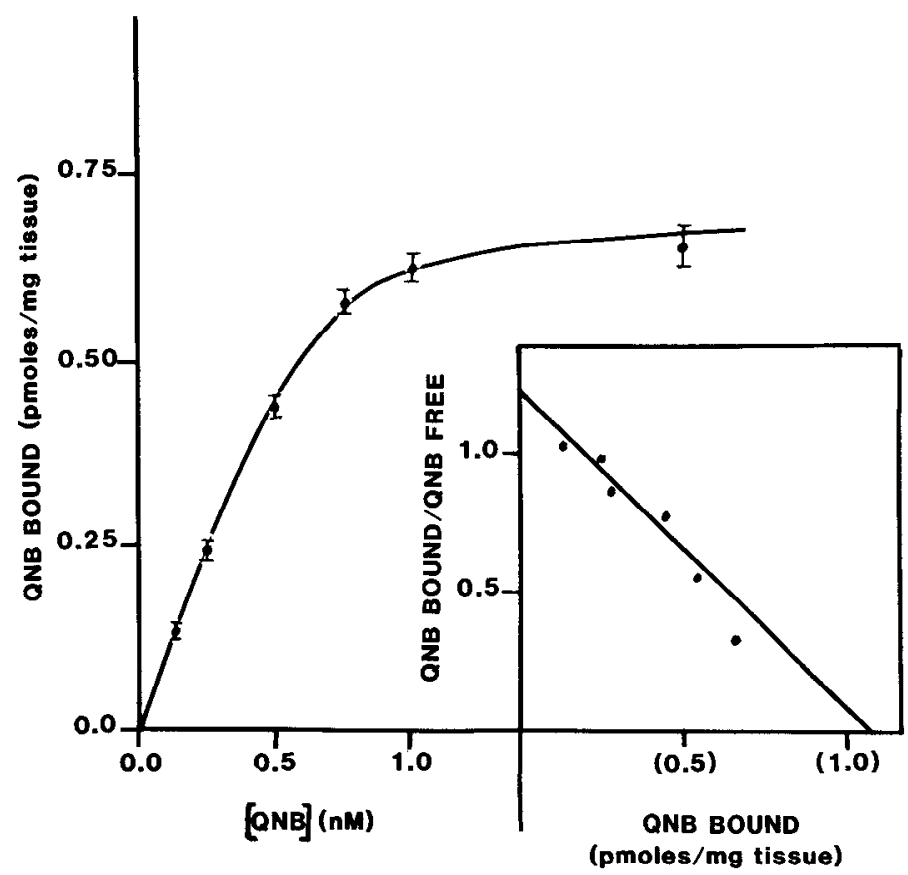

Figure 2. Saturation curve and Scatchard analysis of $\left[{ }^{3} \mathrm{H}\right] \mathrm{QNB}$ binding to coronal sections of frontal cortex from cingulate cortex to rhinal fissure. Twenty-micrometer serial sections were incubated in 0.125 to $2.0 \mathrm{nM}\left[{ }^{3} \mathrm{H}\right] \mathrm{QNB}$ with or without $1 \mu \mathrm{M}$ atropine and were autoradiographed on LKB Ultrofilm. Film density was quantified with a light pen, and the constant relationship between film density and QNB bound per milligram of tissue $(0.484)$ was used to convert this saturation data. The correlation coefficient for the linear Scatchard plot was 0.86 . This figure represents data from three experiments.

Comparison of $Q N B$ binding to sections and homogenates. $\left[{ }^{3} \mathrm{H}\right] \mathrm{QNB}$ binding to dissected frontal cortex homogenates analyzed by a filtration assay was compared to $\left[{ }^{3} \mathrm{H}\right] \mathrm{QNB}$ binding to tissue sections. Saturation curves and Scatchard analyses were determined for both techniques. Since the data presented throughout this manuscript are expressed as picomoles per milligram of tissue, the amount of protein $(0.21 \pm 0.03 \mathrm{mg})$ per milligram of tissue (dry weight) on sections was determined. This relationship was used to convert the homogenate data from picomoles per milligram of protein to picomoles per milligram of tissue (dry weight). The $B_{\max }$ calculated by Scatchard analysis from tissue sections (Fig. 2) was approximately 3 -fold higher than that obtained from homogenates $(1.10 \mathrm{pmol} / \mathrm{mg}$ of tissue, sections versus $0.33 \mathrm{pmol} / \mathrm{mg}$ of tissue, homogenates); $K_{D}$ values were similar $(0.89 \mathrm{nM}$, sections versus $0.68 \mathrm{nM}$, homogenates).

Topographical distribution of decrements in muscarinic receptors. A decrease in muscarinic receptors was visually apparent in brain sections incubated in $1 \mathrm{nM}\left[{ }^{3} \mathrm{H}\right] \mathrm{QNB}$. from rats sacrificed $24 \mathrm{hr}$ after exposure to repeated doses of sublethal soman over 30 days (Fig. $3, A$ to $C$ ). Decrements in binding appeared in telencephalic regions-cortex, caudate-putamen, hippocampal body, and dentate gyrus (Fig. $3, A$ and $B$ ). Repeated soman exposure uniformly reduced muscarinic receptors in the outside (layers I to IV) and inside (layer VI) bands of cortex. Reductions in QNB binding appeared uniformly over the subiculum, regio superior, regio inferior, area dentata, and hilus. Autoradiographic densities were high over the caudate-putamen (Fig. 3, $A a$ and $A b$ ) except where the fiber bundles of the internal capsule passed through and minor decreases were observed after soman exposure. Decrements in binding were also observed in the piriform cortex (Fig. $3, A a$ and $A b$ ), amygdala, and septum (Fig. $3 A b$ ). The corpus callosum, internal capsule, alveus, and globus pallidus (Fig. $3, A$ and $B$ ) were unlabeled in these autoradiograms.
Although regions of the diencephalon, such as thalamus and hypothalamus, showed some differentiation into specific areas within the muscarinic receptor autoradiogram, no decrements in receptor density appeared in brains from the soman-treated rats (Fig. 3, $A d$ and $B a$ to $B c$ ). Higher densities of muscarinic receptors highlighted the anteroventral thalamus (Fig. 3Ad), but $Q N B$ binding did not decrease in soman-treated rats.

In the mesencephalic regions, QNB binding decreased in the superior colliculus, mainly in the superficial grey layer (Fig. 3, $B d, C a$ and $C b$ ) and in the central grey (Fig. 3, Bd and $C a$ ). QNB binding to the inferior colliculus was similar in control and soman-treated rats (Fig. $3 \mathrm{Cc}$ ).

In the metencephalic regions, decreases in QNB binding in motor trigeminal nucleus (fifth) were observed (Fig. $3 \mathrm{Ca}$ ) but not in the nucleus of the facial nerve (seventh) (Fig. $3 \mathrm{Cb}$ ). No decreases in $\mathrm{QNB}$ binding to reticular formation or pontine nuclei were observed (Fig. $3, B b$ to $B d$ ).

In the myelencephalon, the hypoglossal nuclei and nucleus tractus solitarius had higher QNB binding than adjacent regions without showing any differences between control and soman-treated rats (Fig. $3 C d$ ). The cerebellum was very low in QNB binding and similar between controls and experimental rats (Fig. $3 \mathrm{Cd}$ ).

Recovery of muscarinic receptor binding. By analyzing the same brain section from rats sacrificed at different times after the last soman injection, the time course of recovery can be analyzed. Initially, at $1 \mathrm{hr}$ and $24 \mathrm{hr}$ after soman exposure was stopped, the $\left[{ }^{3} \mathrm{H}\right] \mathrm{QNB}$ binding was decreased in hippocampal body, cortex, superior colliculus, and central grey (Fig. 4). Gradually, the $\left[{ }^{3} \mathrm{H}\right] \mathrm{QNB}$ binding increased in these brain regions, approaching control values by 12 to 24 days.

Quantitation of the decrements and recovery of muscarinic receptors. Quantitation of the film densities of selected brain regions within muscarinic receptor autoradiograms from rats sacrificed $24 \mathrm{hr}$ after the last injection revealed decreases in frontal cortex (layers I to IV and VI), caudate-putamen, lateral septum, parietal cortex (I to IV and VI), hippocampal body, dentate gyrus (hilus and molecular layer), superior colliculus, central grey, and motor trigeminal nucleus (fifth) of somantreated rats relative to controls (Table I). In general, the optical densities of these brain regions in soman-treated rats were 67 to $80 \%$ of control. The Student's $t$ test demonstrated that these differences were significant at $p<0.05$. No significant differences were observed in the thalamic nuclei (anteroventral, ventrolateral, or medial geniculate), hypothalamic nuclei (dorsal medial), reticular formation, pontine nuclei, inferior colliculus, the nucleus of the seventh (facial) nerve, or cerebellum.

Analysis of the time course of recovery in brain regions where significant decreases occurred at $24 \mathrm{hr}$ indicated a similar time course of recovery for the different brain areas (Fig. 5). Recovery appeared to be linear; therefore, as an estimate of recovery we analyzed the recovery data by linear regression. Linear regression analyses revealed similar rates of recovery for the examples selected: superior colliculus $(0.000253 \mathrm{pmol} / \mathrm{mg}$ of tissue $/ \mathrm{hr})$ and frontal and parietal cortex $(0.000261 \mathrm{pmol} / \mathrm{mg}$ of tissue/hr) and a slightly slower rate of recovery for the hippocampal body $(0.000242 \mathrm{pmol} / \mathrm{mg}$ of tissue $/ \mathrm{hr})$. These slopes were not statistically different from each other. The time for $50 \%$ recovery was 14 days for superior colliculus, 16 days for cortex, and 19 days for hippocampal body. The rates of recovery are within a similar range for all of the brain regions analyzed.

Saturation and Scatchard analyses of muscarinic receptor binding in soman-treated rats. Saturation curves of $\left[{ }^{3} \mathrm{H}\right] \mathrm{QNB}$ binding $(0.125$ to $2.0 \mathrm{nM})$ and Scatchard analyses of this data in the frontal cortex of rats revealed a decrease in maximal binding $24 \mathrm{hr}$ after the last injection (Fig. 6). The linear plot of the Scatchard analyses of the control data yields a $K_{D}$ of $0.73 \mathrm{nM}$ and a $B_{\max }$ of $1.02 \mathrm{pmol} / \mathrm{mg}$ of tissue, whereas the 

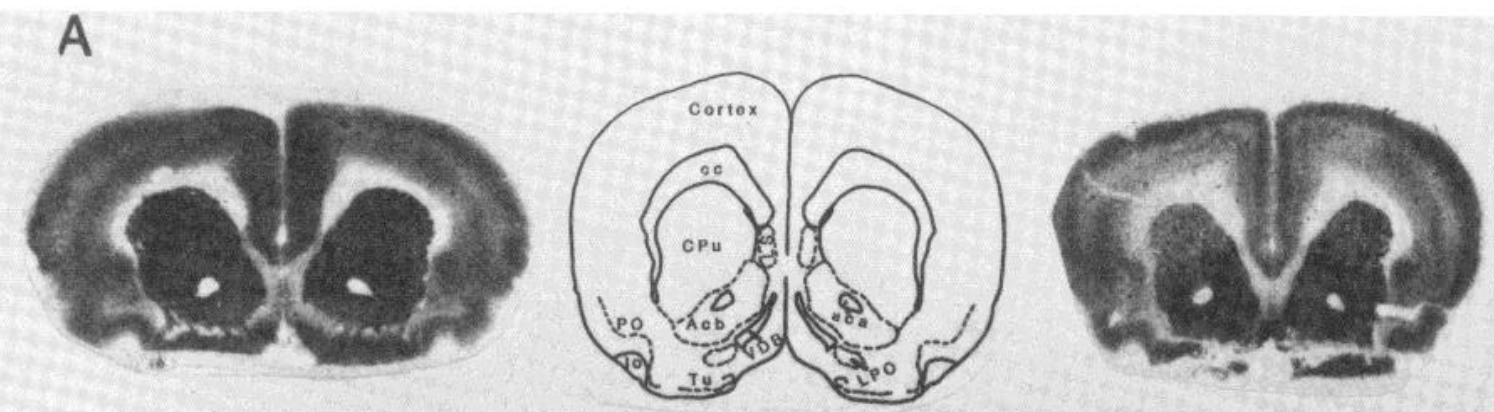

a
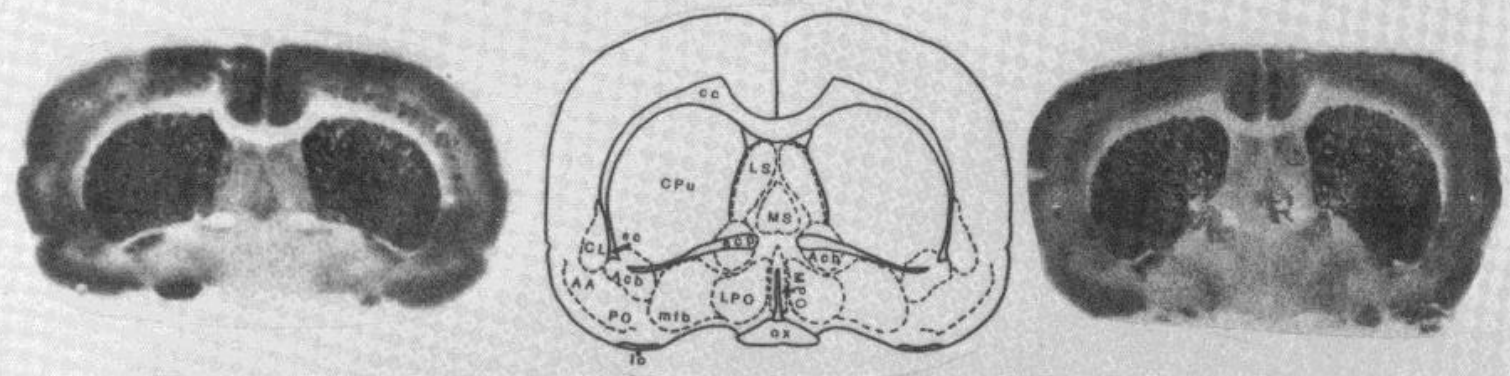

b
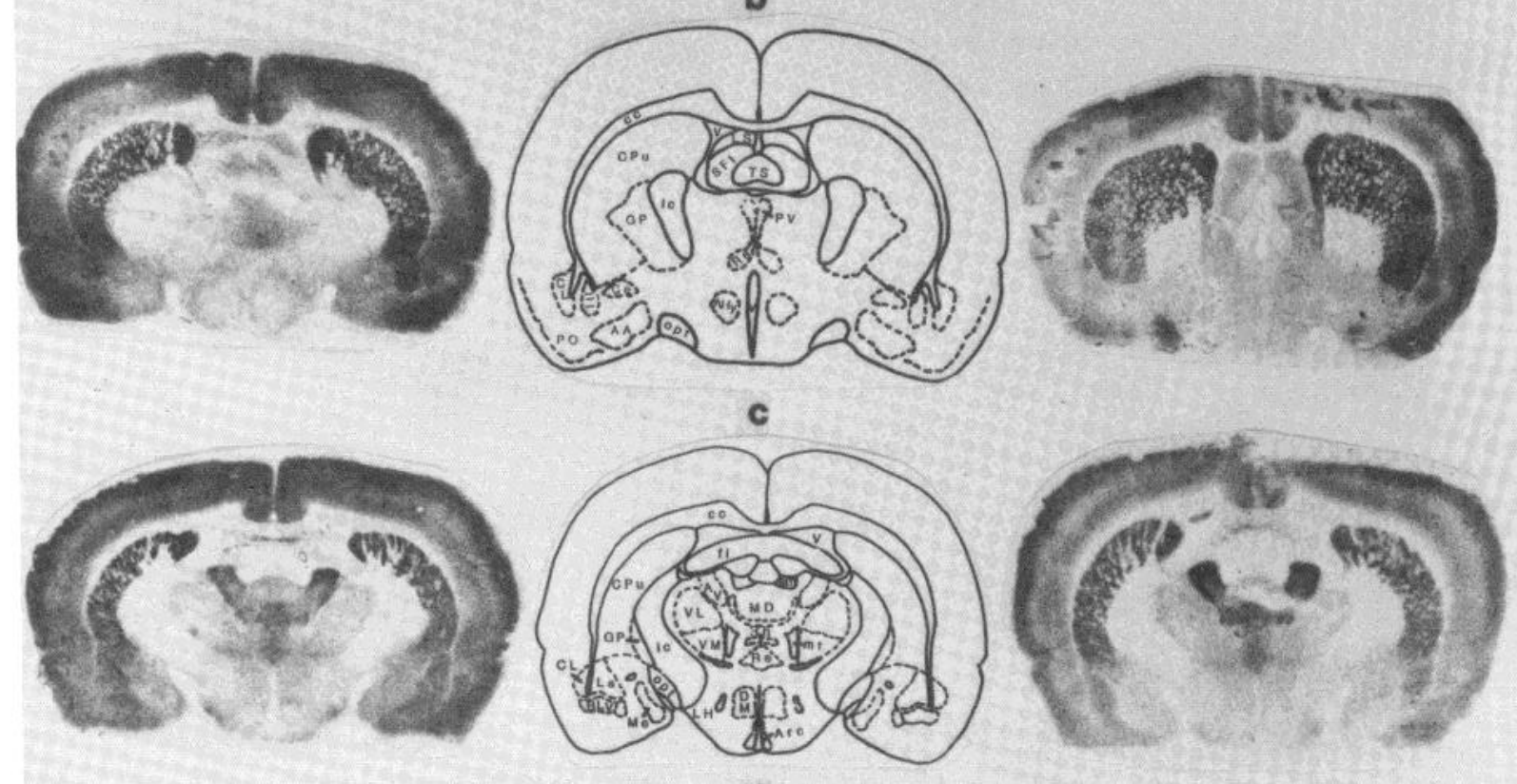

d

\section{CONTROL}

\section{SOMAN}

Figure 3. $A$ to $C$, Autoradiograms of $\left[{ }^{3} \mathrm{H}\right] \mathrm{QNB}$ binding to muscarinic receptors in coronal sections from control rats and rats repeatedly exposed to low doses of soman and killed $24 \mathrm{hr}$ after the last injection. Brain sections were matched during sectioning, incubated in $1 \mathrm{nM}\left[{ }^{3} \mathrm{H}\right]$ $\mathrm{QNB}$, autoradiographed, and photographed under the same conditions to minimize artifactual differences. Darker regions represent a higher concentration of $\left[{ }^{3} \mathrm{H}\right] \mathrm{QNB}$ binding. Line drawings were compiled from a stereotaxic atlas of rat brain (Pellegrino et al., 1979) to match these brain sections and were labeled according to Paxinos and Watson (1982). These figures represent one of six experiments. $A A$, anterior amygdaloid area; $a c a$, anterior commissure, anterior; $A c b$, accumbens nucleus; $a c p$, anterior commissure, posterior; $A H y$, anterior hypothalamic area; $A m b$, ambiguus nucleus; $A P T$, anterior pretectal area; $A q$, cerebral aqueduct (Sylvius); $A r c$, arcuate hypothalamic nucleus; $A V$, anteroventral thalamic nucleus; $B L$, basal amygdaloid; $B L V$, basolateral amygdaloid nucleus, ventral part; $b s c$, brachium of the superior colliculus; $c c$, corpus callosum; $C e$, central amygdaloid nucleus; $C G$, central (periaqueductal) grey; $C L$, claustrum; $c p$, cerebral peduncle, basal part; $C P u$, caudate putamen (striatum); $c s c$, commissure of the superior colliculus; $C u$, cuneate nucleus; $D G$, dentate gyrus; $D L G$, dorsal lateral geniculate nucleus; $D M$, dorsomedial hypothalamic nucleus; $D K$, nucleus of Darkschewitsch; dsc/oc, dorsal spinocerebellar tract/olivocerebellar tract; DTg, dorsal tegmental nucleus (Gudden); $e c$, external capsule; $E n t$, entorhinal cortex; $E W$, accessory oculomotor nucleus (Edinger-Westphal); $f$, fornix; $f i$, fimbria of the hippocampus; $G P$, globus pallidus; $H P C$, hippocampus; $I C$, inferior colliculus; $i c$, internal capsule; $L a$, lateral amygdaloid nucleus; $L C$, locus coeruleus; $L D$, laterodorsal thalamic nucleus; $L H$, lateral hypothalamic area; $l o$, lateral olfactory tract; $L P$, lateral posterior thalamic nucleus (pulvinar); $L P O$, lateral preoptic area; $L R t$, lateral reticular nucleus; $L S$, lateral septum; $L V e$, lateral vestibular nucleus; $m c p$, middle cerebellar peduncle; $M D$, mediodorsal thalamic nucleus; $M e$, medial amygdaloid nucleus; $m f b$, medial forebrain bundle; $M G$, medial geniculate nucleus; $m l$, medial lemniscus; $m l f$, medial longitudinal fasciculus; $m m$, medial mammillary nucleus; Mo5, motor trigeminal nucleus; $m p$, 

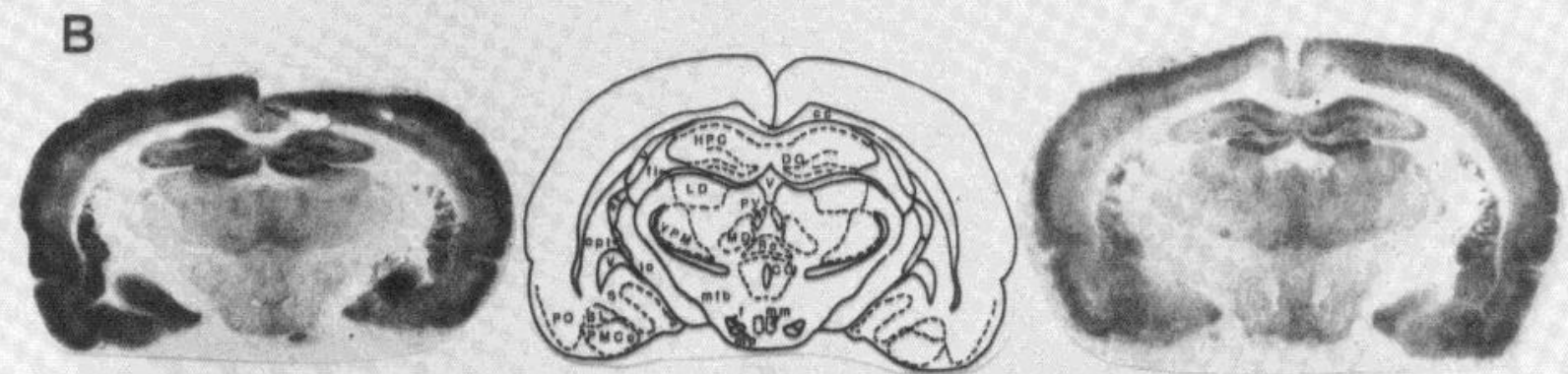

a
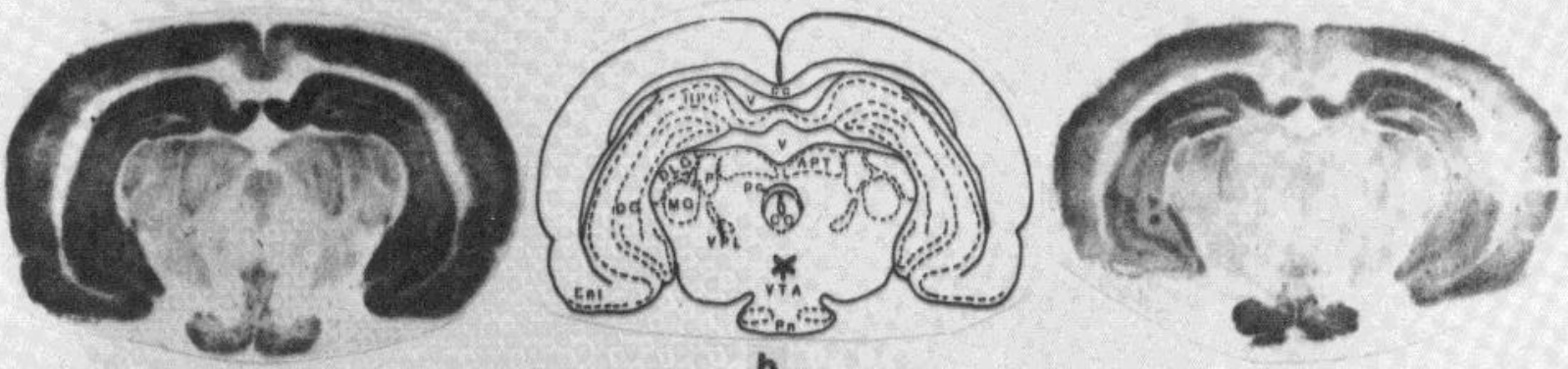

b
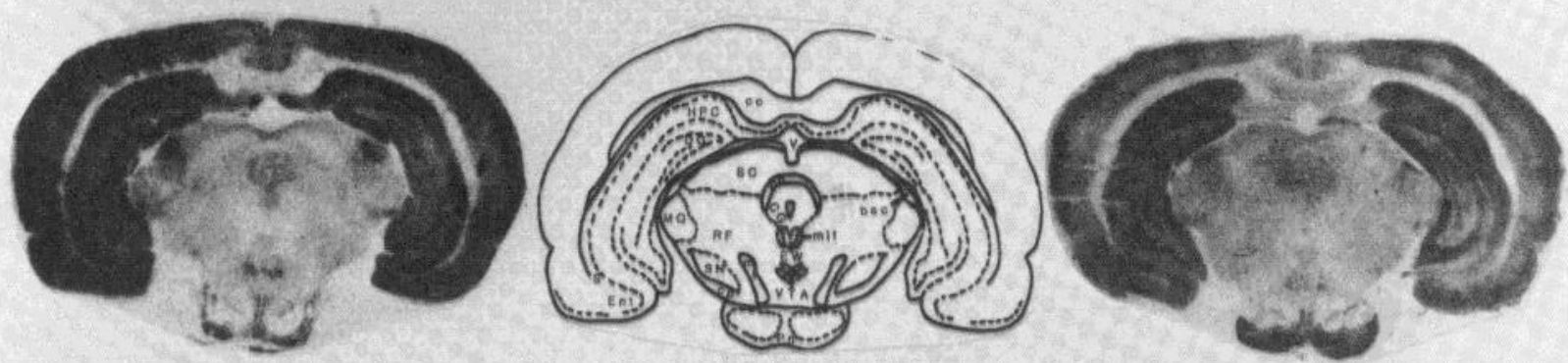

c

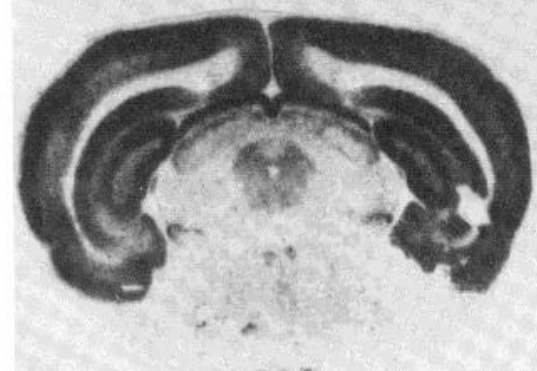

CONTROL

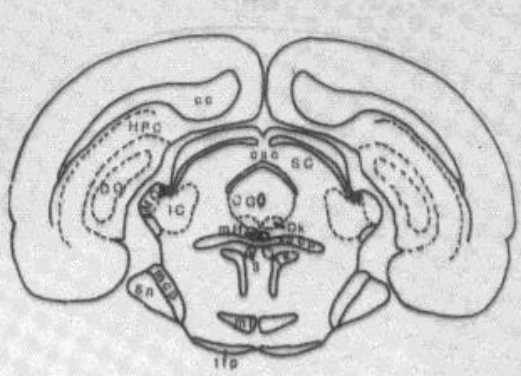

d

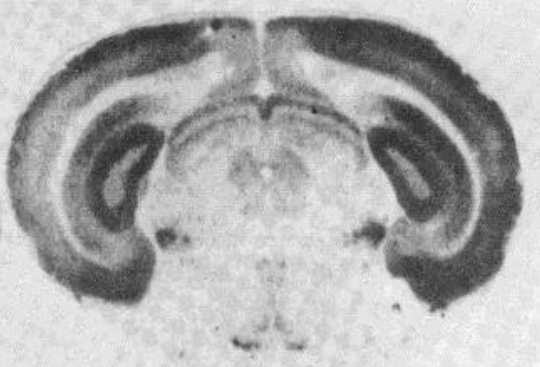

SOMAN

mammillary peduncle; $M P O$, medial preoptic area; $M S$, medial septal nucleus; $M S O$, medial superior olive; $m t$, mammillothalamic tract; $M V e$, medial vestibular nucleus; opt, optic tract; $o x$, optic chiasm; $p c$, posterior commissure; $P M C o$, posteromedial cortical amygdaloid nucleus; $P n$, pontine nucleus; $P O$, primary olfactory (piriform) cortex; $P V$, paraventricular thalamic nucleus; $p y$, pyramidal tract; $R e$, reuniens thalamic nucleus; $R F$, reticular formation; $R h$, rhomboid thalamic nucleus; $S$, subiculum; $S C$, superior colliculus; $s c p$, superior cerebellar peduncle; $S F i$, septofimbrial nucleus; $s m$, stria medullaris of the thalamus; $S N$, substantia nigra; $S o l$, nucleus of the solitary tract; $S p 5$, spinal tract of the trigeminal nerve; $S p 5 O$, nucleus of the spinal tract of the trigeminal nerve, oral part; $S p 5 i$, nucleus of the spinal tract of the trigeminal nerve, interpositus part; SpVe, spinal vestibular nucleus; $s t$, stria terminalis; $t f p$, transverse fibers of the pons; TS, triangular septal nucleus; $t s$, tectospinal tract; $T u$, olfactory tubercle; $t z$, trapezoid body; $V$, ventricle; $V D B$, nucleus of the vertical limb of the diagonal band (Broca); $V L$, 

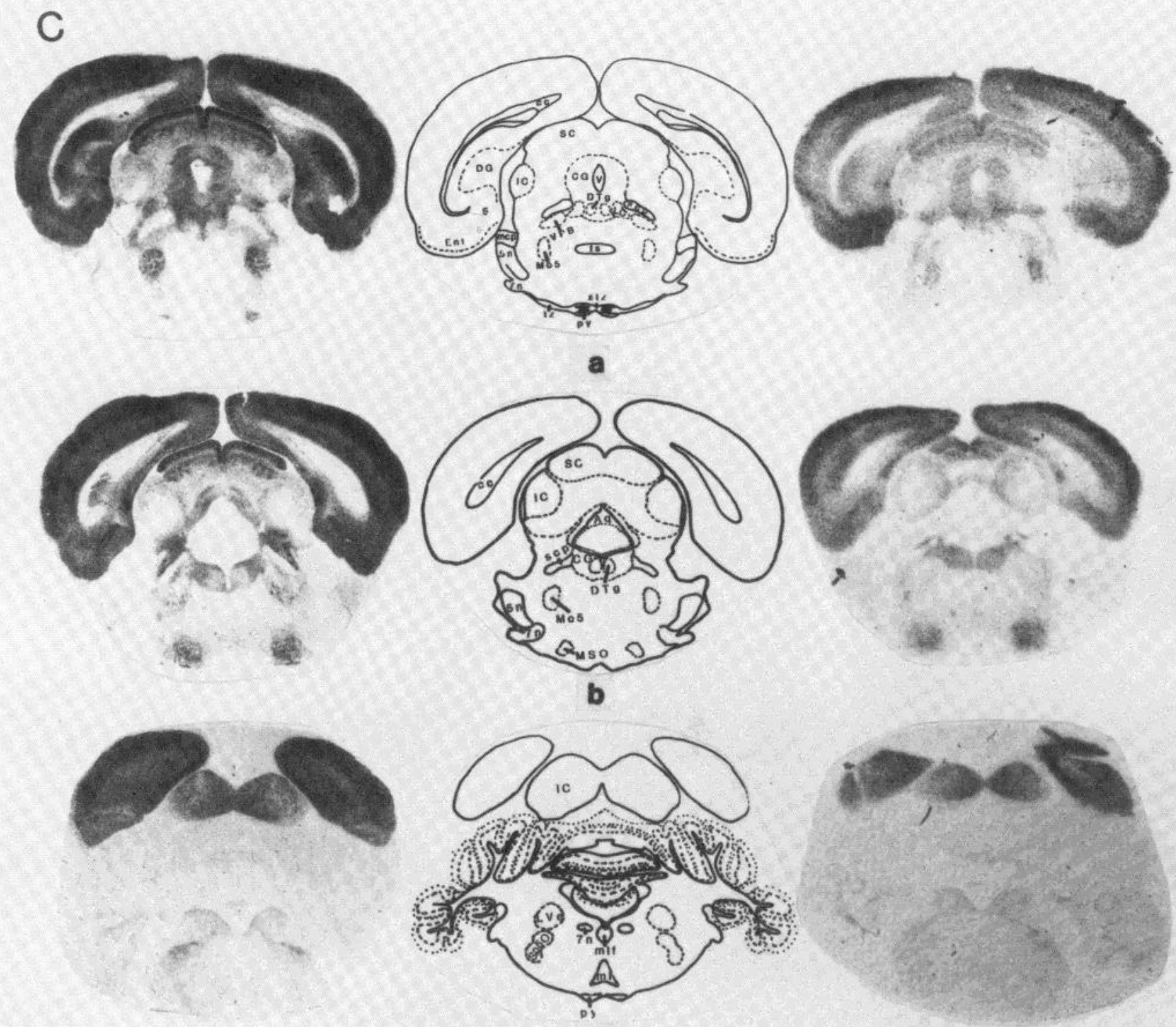

b
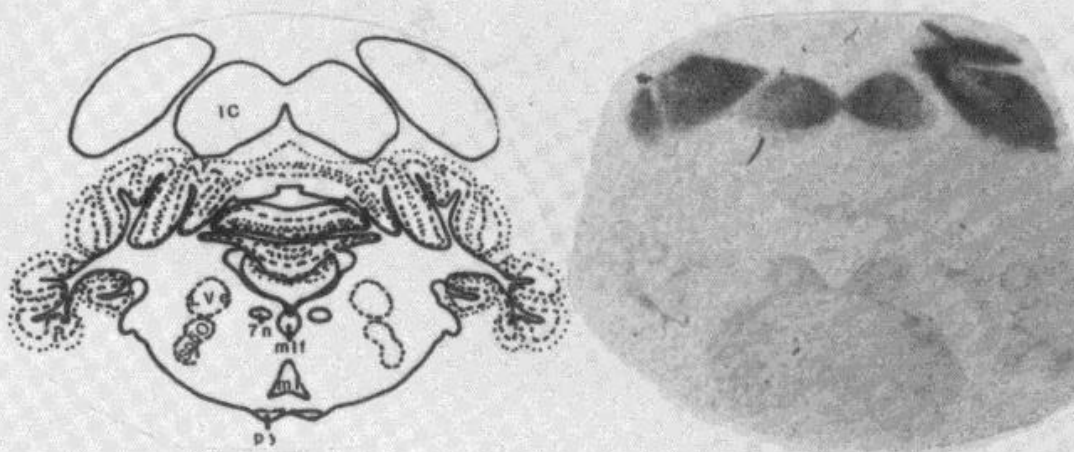

c

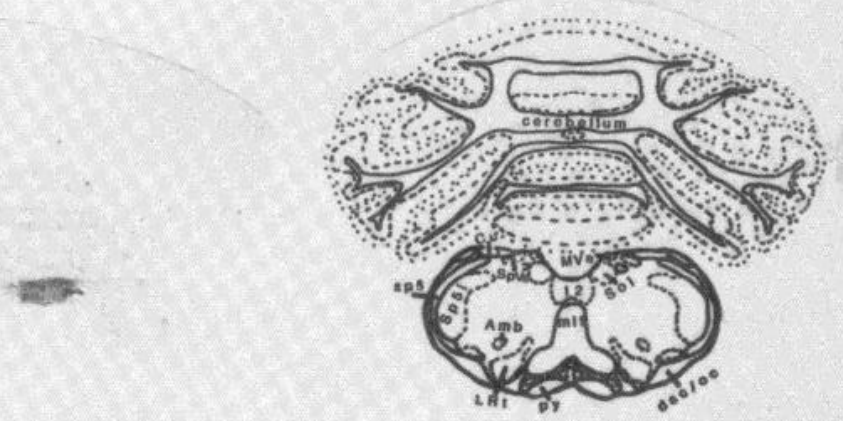

CONTROL

d

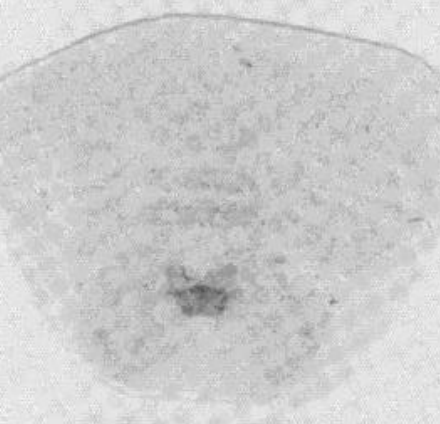

SOMAN

ventrolateral thalamic nucleus; $V M$, ventromedial thalamic nucleus; $V P B$, ventral (medial) parabrachial nucleus; $V P L$, ventroposterior thalamic nucleus, lateral part; VPM, ventroposterior thalamic nucleus, medial part; VTA, ventral tegmental area (Tsai); $x s c p$, decussation of the superior cerebellar peduncle; $x t z$, decussation of the trapezoid body; $7 n$, facial nerve; $5 n$, trigeminal nerve; 3 , principal oculomotor nucleus; 12 , hypoglossal nucleus. 


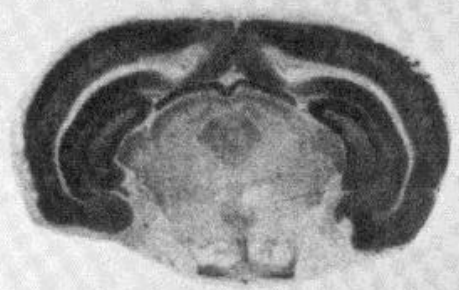

\section{control}
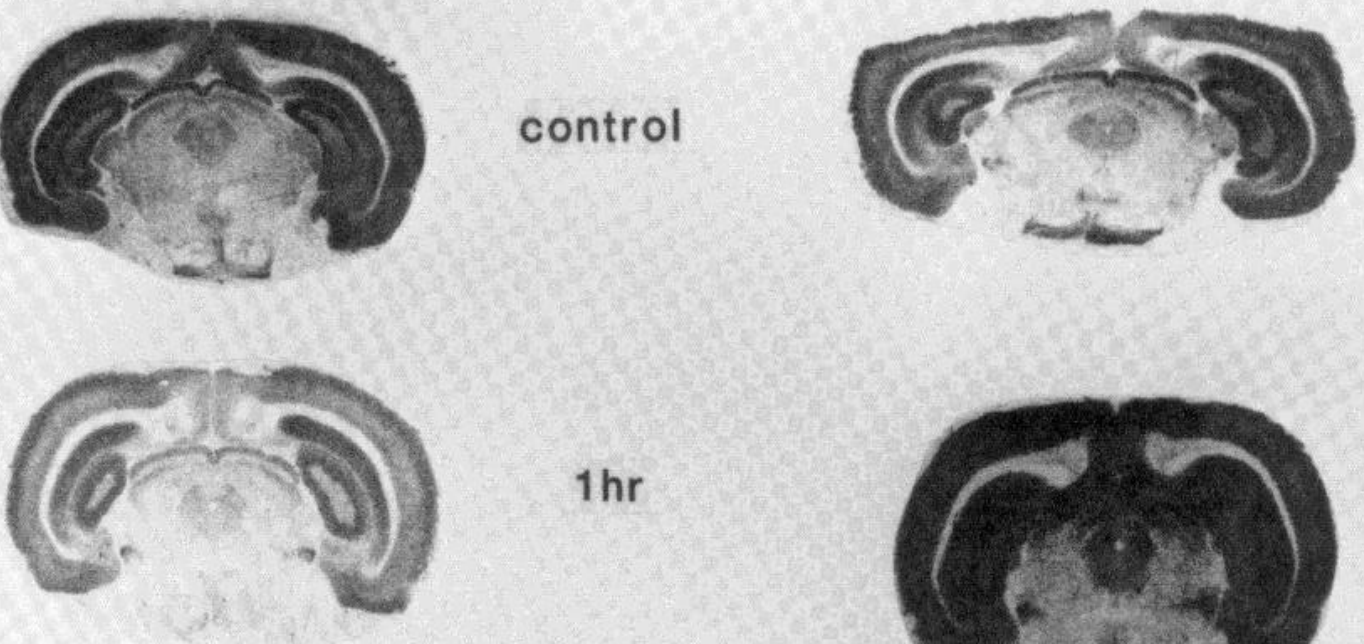

$1 \mathrm{hr}$

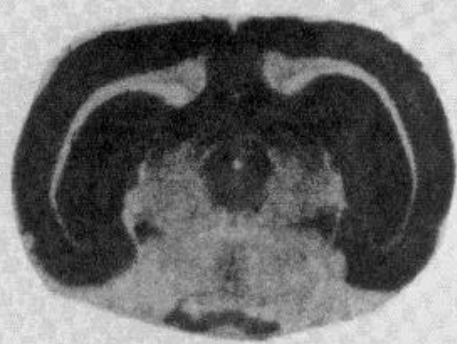

12 day

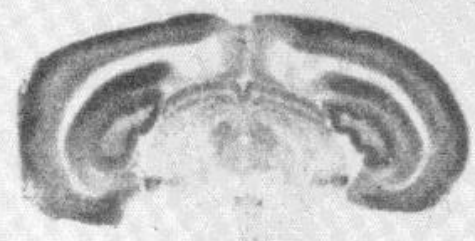

\section{$24 \mathrm{hr}$}

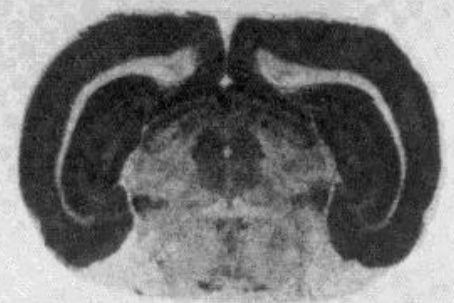

\section{4day}

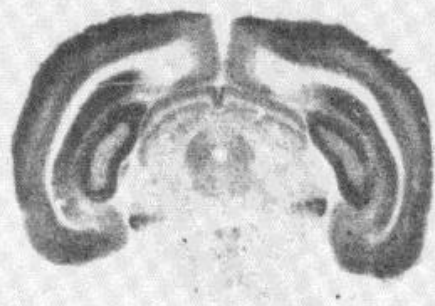

\section{3day}

Figure 4. Autoradiographs of $\left[{ }^{3} \mathrm{H}\right] \mathrm{QNB}$ binding to muscarinic receptors in a coronal section of hindbrain from a control rat in comparison with rats treated with sublethal doses of soman and killed at different times after the last injection. Matched sections illustrate the decrement and recovery of QNB binding after soman exposure. This figure represents one of six experiments. 
TABLE I

Quantitalion of $\left[{ }^{3} H\right] Q N B$ binding to muscarinic receptors in autoradiograms of selected brain regions from soman-treated rats in comparison with matched control sections

Caudate-putamen, lateral septum, and frontal cortex were measured in Figure $3 A b$; dentate gyrus, hippocampal body, parietal cortex, central grey, and superior colliculus were measured in Figure $3 B d$. Brains from four to six rats were analyzed for both soman-treated (24 hr after last injection) and controls. The $\left[{ }^{3} \mathrm{H}\right] \mathrm{QNB}$ bound per milligram of tissue is expressed for the control brains.

\begin{tabular}{lcc}
\hline \multicolumn{1}{c}{ Brain Regions } & $\begin{array}{c}\text { Percentage of Control } \\
\text { Soman-treated (24 hr) }\end{array}$ & $\begin{array}{c}\text { QNB Bound to Control } \\
\text { (pmol/mg of tissue) }\end{array}$ \\
\hline Frontal cortex I to IV & mean $\pm S E M(N)$ & mean $\pm S E M(N)$ \\
Frontal cortex VI & $74.1 \pm 4.6(6)^{a}$ & $0.686 \pm 0.021(6)$ \\
Lateral septum & $71.4 \pm 4.3(6)^{a}$ & $0.788 \pm 0.020(6)$ \\
Caudate-putamen & $74.7 \pm 5.8(6)^{a}$ & $0.457 \pm 0.025(6)$ \\
Hypothalamus (dorsomedial) & $78.8 \pm 6.7(6)^{a}$ & $0.804 \pm 0.038(6)$ \\
Anteroventral thalamus & $94.2 \pm 9.2(6)$ & $0.260 \pm 0.019(6)$ \\
Ventrolateral thalamus & $103.3 \pm 5.0(6)$ & $0.613 \pm 0.027(6)$ \\
Parietal cortex I to IV & $90.5 \pm 6.0(5)$ & $0.258 \pm 0.015(6)$ \\
Parietal cortex VI & $70.1 \pm 6.5(6)^{a}$ & $0.688 \pm 0.029(6)$ \\
Hippocampal body & $68.1 \pm 5.2(6)^{a}$ & $0.820 \pm 0.035(6)$ \\
Dentate gyrus, mol. & $71.3 \pm 7.9(6)^{a}$ & $0.819 \pm 0.049(6)$ \\
Dentate gyrus, hilus & $78.2 \pm 7.2(6)^{a}$ & $0.719 \pm 0.049(6)$ \\
Superior colliculus & $70.8 \pm 5.9(6)^{a}$ & $0.554 \pm 0.028(6)$ \\
Central grey & $67.1 \pm 5.5(6)^{a}$ & $0.598 \pm 0.022(6)$ \\
Reticular formation & $80.0 \pm 7.5(6)^{a}$ & $0.359 \pm 0.016(6)$ \\
Medial geniculate & $85.1 \pm 13.5(6)$ & $0.210 \pm 0.017(6)$ \\
Pontine nuclei & $79.5 \pm 13.7(5)$ & $0.303 \pm 0.034(6)$ \\
Inferior colliculus & $84.8 \pm 11.0(6)$ & $0.516 \pm 0.059(5)$ \\
Nucleus of 5th nerve & $83.8 \pm 7.9(4)$ & $0.464 \pm 0.025(5)$ \\
Nucleus of 7th nerve & $78.5 \pm 6.9(6)^{a}$ & $0.433 \pm 0.024(6)$ \\
Cerebellum & $82.3 \pm 7.0(4)$ & $0.417 \pm 0.026(6)$ \\
\hline
\end{tabular}

${ }^{a} p<0.05$ by the Student's $t$ test

soman-treated group at $24 \mathrm{hr}$ yields a $K_{D}$ of $0.61 \mathrm{nM}$ and a $B_{\text {ma }}$ of $0.68 \mathrm{pmol} / \mathrm{mg}$ of tissue (Fig. 6 , inset). No statistical differences were found between the slopes of these linear regressions. The decrease in maximal binding in the soman-treated rats was $66.7 \%$ of control. Therefore, soman exposure appears to decrease the maximal binding without significantly affecting the affinity. By 24 days after the last injection, the maximal binding of QNB approached control levels, as evidenced by a $B_{\max }$ of $0.94 \mathrm{pmol} / \mathrm{mg}$ of tissue and a $K_{D}$ of $0.66 \mathrm{nM}$.

\section{Discussion}

Repeated exposure to soman decreased the concentration of muscarinic receptors in many brain regions but not all, as assessed by quantitative receptor autoradiography. In those brain areas with significant decrements in $\left[{ }^{3} \mathrm{H}\right] \mathrm{QNB}$ binding, recovery to near normal values occurred by 24 days post-soman treatment. Scatchard analyses of saturation curves for $\left[{ }^{3} \mathrm{H}\right]$ QNB binding to frontal cortex (see Fig. 6) revealed a significant decrease in maximal binding $\left(B_{\max }\right)$ for the group analyzed 24 hr post-soman treatment, whereas the $B_{\max }$ for the 24 -day postsoman treatment group was not significantly different from control. The affinity $\left(K_{D}\right)$ was similar in all groups. Similar changes in QNB binding kinetics have been reported for repeated exposures to other anticholinesterase agents (Schiller, 1979; Ehlert et al., 1980a, b; Costa et al., 1981; Schwab et al., 1981; Yamada et al., 1983). These observations suggest that synaptic transmitter concentration may modulate the sensitivity of postsynaptic receptors (Bito and Dawson, 1970), perhaps through increased endocytosis and degradation of receptors (Klein et al., 1979).

Computer-assisted densitometric analysis of autoradiograms was used to assess $\left[{ }^{3} \mathrm{H}\right] \mathrm{QNB}$ binding to specific brain areas. To determine the relationship between film density and picomoles of $\left[{ }^{3} \mathrm{H}\right] \mathrm{QNB}$ hound, we used saturation curves generated by exposing frontal coronal brain sections to a range of $\left[{ }^{3} \mathrm{H}\right] \mathrm{QNB}$ concentrations and by quantitating the film density and radioactivity in the frontal cortex from the same sections. The relationship between film density and $\left[{ }^{3} \mathrm{H}\right] \mathrm{QNB}$ bound was approximately linear within the range of radioactivity and film density used in these experiments. This method of standardization is different from the use of soluble radioactive ligand in brain pastes as standards (Rainbow et al., 1982; Unnerstall et al., 1982) and has the distinct advantage that the distribution of radioactivity per brain area is similar in standards and unknowns. Films were also exposed to $\left[{ }^{14} \mathrm{C}\right]$ methyl methacrylate standards along with the brain sections to adjust for differences in film exposure or development. When $\left[{ }^{3} \mathrm{H}\right] \mathrm{QNB}$ bound to frontal cortices scraped from dried sections was compared to that bound to cortical homogenates, the $B_{\max }$ was 3fold higher for sections than homogenates. The greater binding of $\left[{ }^{3} \mathrm{H}\right] \mathrm{QNB}$ to coronal sections than to homogenates may be a result of damage to binding sites during homogenization and sonication, possibly by enhanced protease activity.

Decrements in muscarinic receptors as assessed by $\left[{ }^{3} \mathrm{H}\right] \mathrm{QNB}$ binding were observed in specific brain areas $24 \mathrm{hr}$ after repeated exposure to soman. These decrements were not uniform throughout the brain. Most of the brain regions that showed significant decrements in QNB binding were in the telencephalon. The greatest decrements occurred in the telencephalic areas of cortex and hippocampus. One reason for this differential response might be the substantially longer duration of the ACh elevation in cortex and hippocampus than in brain stem or midbrain following a $0.9 \mathrm{LD}_{50}$ dose of soman (Shih, 1982). The topographical distribution of decrements in $\left[{ }^{3} \mathrm{H}\right]$ QNB binding was similar to that found after repeated exposure to DFP (Churchill et al., 1984). Quantitation of autoradiograms $24 \mathrm{hr}$ post-DFP or post-soman exposure showed similar decreases (65 to $80 \%$ of control) in $\left[{ }^{3} \mathrm{H}\right] \mathrm{QNB}$ binding for the following telencephalic regions: cortex, caudate-putamen, lateral septum, hippocampal body, and dentate gyrus. Likewise, 

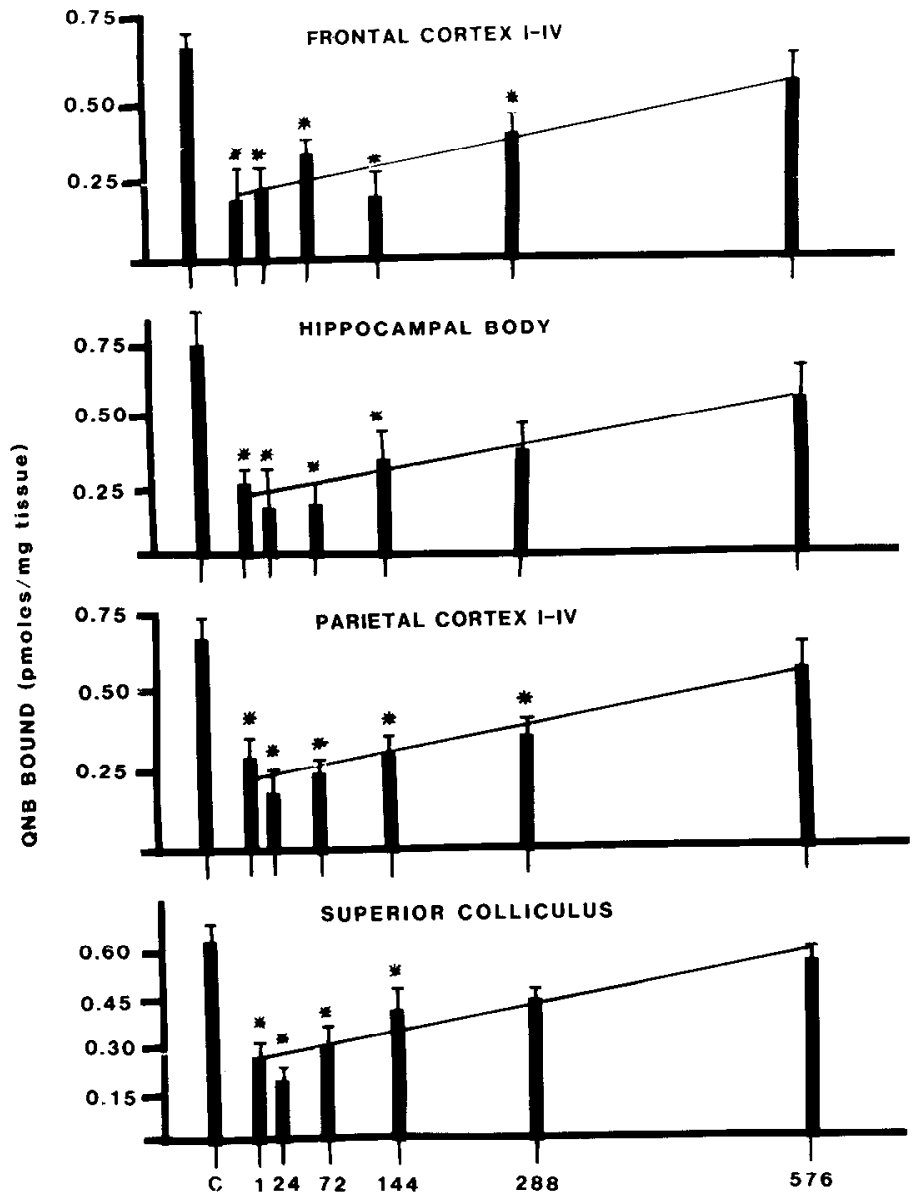

TIME AFTER LAST DOSE (H)

Figure 5. Recovery curves for $\left[{ }^{3} \mathrm{H}\right] \mathrm{QNB}$ binding to selected brain regions where decrements in QNB binding occurred after soman exposure. The autoradiograms from matched coronal sections incubated in $1 \mathrm{nM}\left[{ }^{3} \mathrm{H}\right]$ QNB were quantified by computer-assisted densitometry. One-way analysis of variance and the Dunnett's multiple comparison test were used to calculate significant differences from control (asterisks indicate $p<0.05$ ). The correlation coefficients for the linear regression analyses were $0.90,0.95,0.94$, and 0.92 for frontal cortex (I to IV), parietal cortex (I to IV), hippocampal body, and superior colliculus, respectively.

quantitative decreases of 70 to $80 \%$ of control were obtained when $\left[{ }^{3} \mathrm{H}\right] \mathrm{QNB}$ binding to dissected brain homogenates was determined after repeated exposure to other anticholinesterase agents (Gazit et al., 1979; Ehlert et al., 1980a, b; Costa et al., 1981; Schwab et al., 1981; Yamada et al., 1983).

In general, regional decreases in $\left[{ }^{3} \mathrm{H}\right] \mathrm{QNB}$ binding induced by multiple exposures to anticholinesterase agents were similar among the different anticholinesterase agents; however, there were a few notable differences. For example, in the pontine nuclei, a significant decrement ( $67 \%$ of control) occurred after repeated DFP exposure (Churchill et al., 1984), whereas no significant decreases occurred after repeated soman exposure. Likewise, Gazit et al. (1979) noted a decrease in $\left[{ }^{3} \mathrm{H}\right] \mathrm{QNB}$ binding in the thalamus after exposure to Tetram, whereas no changes were detected in the thalamic areas after soman or DFP exposure (Yamada et al., 1983; Churchill et al., 1984).

Similarities in decrements of muscarinic receptors induced by soman or DFP exposure are in striking contrast to the behavioral and brain regional glucose use changes caused by single, near-lethal doses of these two agents. Soman at nearlethal doses induced strong persistent seizures in rats (Mc-
Donough et al., 1983a), whereas DFP only produced peripheral cholinomimetic effects with brief convulsant-like activity occurring just prior to death. Associated with the intense seizure activity induced by soman was a marked elevation of local cerebral glucose utilization in many brain regions as assessed by the 2-deoxyglucose technique (McDonough et al., 1983a). On the other hand, DFP had a minimal impact on local cerebral glucose utilization in the brain except for retinal-mediated activation of the superficial layer of the superior colliculus (Nelson et al., 1978; Pazdernik et al., 1982). The similarity in muscarinic receptor down-regulation, in contrast to the major differences between these two agents on glucose utilization in the brain, suggests that soman-induced seizures may be in part dependent on noncholinergic processes (O'Neill, 1981; Samson et al., 1984).

Conspicuous neuropathology was observed in the piriform cortex of 5 of 36 experimental rats during inspection of the receptor autoradiograms (Churchill et al., 1983). Extensive cell loss and tissue fragmentation in the piriform cortex were confirmed by hematoxylin and eosin staining of adjacent sections. McLeod et al. (1984) and Lemercier et al. (1983) also reported extensive neuropathology in the piriform cortex in all rats that had intense soman-induced seizures. $\left[{ }^{3} \mathrm{H}\right] \mathrm{QNB}$ binding in the piriform cortex of these five experimental rats was extremely low $\left(45.4 \pm 7.8 \%\right.$ of control), whereas $\left[{ }^{3} \mathrm{H}\right] \mathrm{QNB}$ binding to frontal cortex and other telencephalic brain regions in these five rats was similar to that observed in brains from rats without notable pathology. This gross irreversible pathology in selected brain regions of some rats exposed to soman suggests that inferences about mechanisms underlying the changes in $\left[{ }^{3} \mathrm{H}\right]$ QNB binding after soman exposure should be made cautiously. For example, the decrements in QNB binding might be the

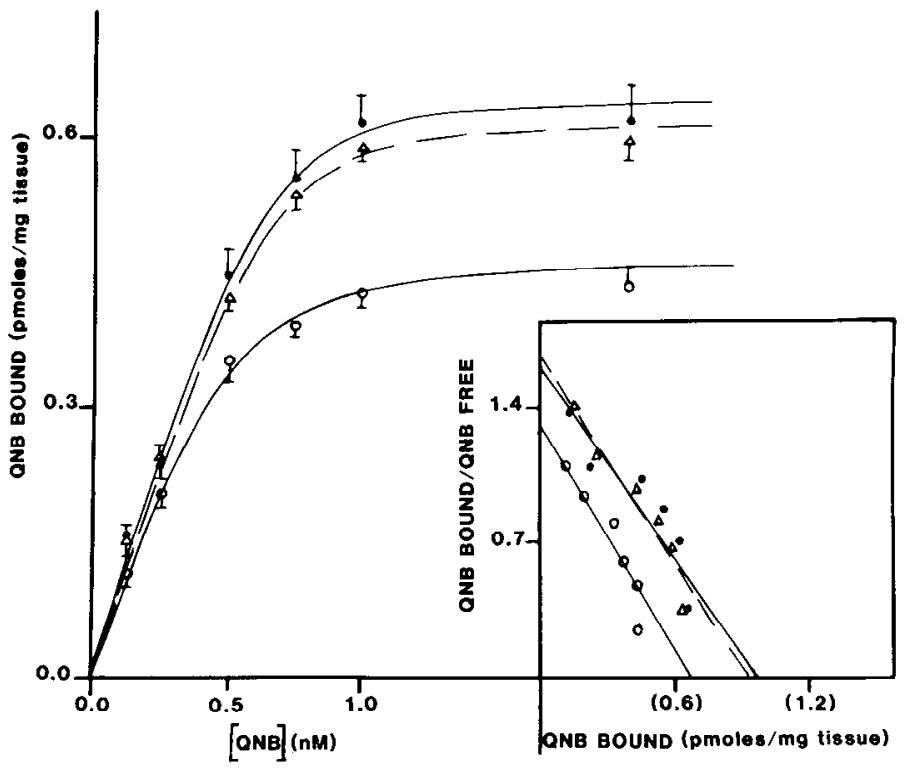

Figure 6. Saturation curves and Scatchard analyses of $\left[{ }^{3} \mathrm{H}\right] \mathrm{QNB}$ binding to muscarinic receptors in frontal cortex from soman-treated and control rats. Average film densities of QNB binding to frontal cortex (I to IV) were quantified from LKB Ultrofilm autoradiograms of sequential coronal sections from the frontal pole of controls (solid circles), soman-treated rats killed $24 \mathrm{hr}$ after last injection (open circles), and soman-treated rats killed 24 days after the last injection (triangles). Maximal binding of QNB was decreased in rats killed 24 hr after the last injection without any change in affinity. Maximal binding recovered to control levels by 24 days after the last exposure. The correlation coefficients for the linear Scatchard plots were 0.89 , 0.87 , and 0.96 for control, $24 \mathrm{hr}$, and 24 days, respectively. This figure represents data from three experiments. 
result of some damage to cholinoceptive processes rather than an adaptive response to excessive cholinergic stimulation. The recovery of $\left[{ }^{3} \mathrm{H}\right] \mathrm{QNB}$ binding with time after cessation of soman exposure supports the view that receptor decrements are an adaptive response to excessive cholinergic stimulation. On the other hand, the return of $\left[{ }^{3} \mathrm{H}\right] \mathrm{QNB}$ binding to normal levels could be at least in part the result of synaptic sprouting of adjacent cholinoceptive processes or repair of damaged processes.

Major advantages of quantitative receptor autoradiogaphy over traditional homogenate procedures include the following. (1) Detailed anatomical distribution of ligand binding sites can be visualized over the entire brain. (2) Quantitation can be determined in specific layers of cortex or hippocampus or in definite nuclei, such as the nucleus of the 5 th or 7 th nerves. (3) Heterogeneity in ligand binding within a particular anatomical region can be detected, and the region selected for analysis can be better defined. (4) Most importantly, signs of neuropathology may be detected in specific brain areas; consequently, the mixing of results from damaged and undamaged tissues can be avoided. Thus, the autoradiographic analysis of receptor alterations provides kinetic and histological information as well as the topographical distribution of the receptor alterations.

Analysis of the recovery of muscarinic receptors after cessation of soman exposure by quantitative autoradiography is a unique contribution of this study. The rate of recovery was compared in several brain regions and was slightly faster in superior colliculus and cortex ( $t_{1 / 2}=14$ to 16 days) than in hippocampal body ( $t_{1 / 2}=19$ days). $\left[{ }^{3} \mathrm{H}\right] \mathrm{QNB}$ binding was slightly below but not significantly different from control values at the last time point evaluated ( 24 days post-soman exposure). Costa et al. (1981) found $\left[{ }^{3} \mathrm{H}\right]$ QNB binding in brain homogenates from mice to be slightly below but not significantly different from control values by 21 days post-disulfoton exposure. The time course of recovery for muscarinic receptors was compared to that for brain cholinesterase activity after soman exposure in a parallel study (McDonough et al., 1983b). A half-life of recovery for brain cholinesterase activity was 8 to 11 days in midbrain, hippocampus, and cortex. A slightly earlier recovery of brain cholinesterase activity than of $\left[{ }^{3} \mathrm{H}\right] \mathrm{QNB}$ binding suggests that these two events may be linked.

\section{References}

Biegon, A., T. C. Rainbow, J. J. Mann, and B. S. McEwen (1982) Neurotransmitter receptor sites in human hippocampus: A quantitative autoradiographic study. Brain Res. 247: 379-382.

Bito, L. Z., and M. J. Dawson (1970) The site and mechanism of the control of cholinergic sensitivity. J. Pharmacol. Exp. Ther. 175: 673684 .

Churchill, L., T. L. Pazdernik, J. L. Jackson, S. R. Nelson, F. E. Samson, and J. H. McDonough, Jr. (1983) Topographical distribution in and recovery of musarinic receptor binding after repeated exposure to soman. Soc. Neurosci. Abstr. 9: 964.

Churchill, L., T. L. Pazdernik, F. Samson, and S. R. Nelson (1984) Topographical distribution of down-regulated muscarinic receptors in rat brains after repeated exposure to diisopropyl fluorophosphate. Neuroscience 11: 463-472.

Costa, L. G., B. W. Schwab, H. Hand, and S. D. Murphy (1981) Decreased muscarinic binding sites in small intestine from mice treated with neostigmine. Life Sci. 29: 1675-1682.

Costa, L. G., B. W. Schwab, and S. D. Murphy (1982) Differential alterations of cholinergic muscarinic receptors during chronic and acute tolerance to organophosphorous insecticides. Biochem. Pharmacol. 31: 3407-3413.

Davies, P. L. (1961) Statistical Methods in Research and Procedures, Ed. 3, p. 41, Oliver and Boyd, London.

Ehlert, F. J., and N. Kokka (1977) Decrease in $\left[{ }^{3} \mathrm{H}\right]$ quinuclidinyl benzilate binding in the longitudinal muscle of the rat ileum following chronic administration of diisopropylfluorophosphate. Proc. West. Pharmacol. Soc. 20:1-7.

Ehlert, F. J., N. Kokka, and A. S. Fairhurst (1980a) Altered $\left[{ }^{3} \mathrm{H}\right]$ quinuclidinyl benzilate binding in the striatum of rats following chronic cholinesterase inhibition with diisopropylfluorophosphate. Mol. Pharmacol. 17: 24-30.

Ehlert, F. J., N. Kokka, and A. S. Fairhurst (1980b) Muscarinic receptor subsensitivity in the longitudinal muscle of the rat ileum following chronic anticholinesterase treatment with diisopropylfluorophosphate. Biochem. Pharmacol. 29: 1391-1397.

Fonnum, F., and D. M. Guttormsen (1969) Changes in acetylcholine content of rat brain by toxic doses of diisopropyl phosphorofluoridate. Experientia 25: 505-506.

Gazit, H., I. Silman, and Y. Dudai (1979) Administration of an organophosphate causes a decrease in muscarinic receptor levels in rat brain. Brain Res. 174: 351-356.

Klein, W. L., N. Nathanson, and M. Nirenberg (1979) Muscarinic acetylcholine receptor regulation by accelerated rate of receptor loss. Biochem. Biophys. Res. Commun. 90: 506-512.

Kuhar, M. J., and H. I. Yamamura (1975) Light autoradiographic localization of cholinergic muscarinic receptors in rat brain by specific binding of a potent antagonist. Nature 253: 560-561.

Lemercier, G., P. Carpentier, H. Sentenac-Roumanou, and P. Morelis (1983) Histological and histochemical changes in the central nervous system of the rat poisoned by an irreversible anticholinesterase organophosphorous compound. Acta Neuropathol. (Berl.) 61: 123129.

Lowry, O. H., N. J. Rosebrough, A. L. Farr, and R. J. Randall (1951) Protein measurement with the Folin phenol reagent. J. Biol. Chem. 193: 265-275.

McDonough, J., B. Hackley, R. Cross, F. Samson, and S. Nelson (1983a) Brain regional glucose use during soman-induced seizures. Neurotoxicology 4: 203-210.

McDonough, J. H., T. M. Shih, A. Kaminskis, J. Jackson, and R. Alvarez (1983b) Depression and recovery of rat blood and brain cholinesterase activity after repeated exposure to soman. Soc. Neurosci. Abstr. 9: 964

McLeod, C. G., Jr., A. W. Singer, and D. G. Harrington (1984) Acute neuropathology in soman-poisoned rats. Neurotoxicology, in press.

Michaelis, M., J. E. Finesinger, F. B. Verster, and R. W. Erickson (1954) The effect of the intravenous injection of DFP and atropine on the level of free acetylcholine in the cerebral cortex of the rabbit. J. Pharmacol. Exp. Ther. 111: 169-175.

Milosevic, M. P. (1970) Acetylcholine content in the brain of rats treated with paraoxon and obidoxime. Br. J. Pharmacol. 39: 732737.

Nelson, S. R., J. Doull, B. A. Tockman, P. J. Cristiano, and F. E. Samson (1978) Regional brain metabolism changes induced by acetylcholinesterase inhibitors. Brain Res. 157: 186-190.

O'Neill, J. J. (1981) Non-cholinesterase effects of anticholinesterases. Fund. Appl. Toxicol. 1: 154-160.

Palacios, J. M., and M. J. Kuhar (1981) Neurotensin receptors are located on dopamine-containing neurons in rat midbrain. Nature 294: 587-589.

Pan, H. S., K. A. Frey, A. B. Young, and J. B. Penney, Jr. (1983) Changes in $\left[{ }^{3} \mathrm{H}\right]$ muscimol binding in substantia nigra, entopeduncular nucleus, globus pallidus, and thalamus after striatal lesions as demonstrated by quantitative receptor autoradiography. I. Neurosci. 3: 1189-1198.

Paxinos, G., and C. Watson (1982) The Rat Brain in Stereotaxic Coordinates. Academic Press, New York.

Pazdernik, T. L., R. S. Cross, K. Mewes, F. Samson, and S. R. Nelson (1982) Superior colliculus activation by retinal nicotinic ganglion cells: A 2-deoxyglucose study. Brain Res. 243: 197-200.

Pellegrino, L. J., A. S. Pellegrino, and A. J. Cushman (1979) A Stereotaxic Atlas of the Rat Brain, Plenum Press, New York.

Penney, J. B., Jr., H. S. Pan, A. B. Young, K. A. Frey, and G. W. Dauth (1981) Quantitative autoradiogaphy of $\left[{ }^{3} \mathrm{H}\right]$ muscimol binding in rat brain. Science 214: 1036-1038.

Rainbow, T. C., W. V. Bleisch, A. Biegon, and B. S. McEwen (1982) Quantitative densitometry of neurotransmitter receptors. J. Neurosci. Methods 5: 127-138.

Rotter, A., N. J. M. Birdsall, A. S. V. Burgen, P. M. Field, E. C. Hulme, and G. Raisman (1979) Muscarinic receptors in the central nervous system of the rat. I. Technique for autoradiographic localization of the binding of $\left[{ }^{3} \mathrm{H}\right]$ propylbenzilylcholine mustard and its distribution in the forebrain. Brain Res Rev. 1: 141-165.

Samson, F. E., T. L. Pazdernik, R. S. Cross, M. P. Giesler, K. Mewes, S. R. Nelson, and J. H. McDonough, Jr. (1984) Soman induced 
changes in brain regional glucose use. Fund. Appl. Toxicol. 4: 51735183.

Schiller, G. D. (1979) Reduced binding of $\left[{ }^{3} \mathrm{H}\right]$-quinuclidinyl benzilate associated with chronically low acetylcholinesterase activity. Life Sci. 24: 1159-1164.

Schwab, B. W., H. Hand, L. G. Costa, and S. D. Murphy (1981) Reduced muscarinic receptor binding in tissues of rats tolerant to the insecticide disulfoton. Neurotoxicology 2: 635-647.

Shih, T. - M. (1982) Time course effects of soman on acetylcholine and choline levels in six discrete areas of the rat brain. Psychopharmacology 78: 170-175.

Uchida, S., K. Takeyasu, T. Matsuda, and H. Yoshida (1979) Changes in muscarinic acetylcholine receptors of mice by chronic administrations of diisopropylfluorophosphate and papaverine. Life Sci. 24:
1805-1812.

Unnerstall, J. R., D. L. Niehoff, M. J. Kuhar, and J. M. Palacios (1982) Quantitative receptor autoradiography using $\left[{ }^{3} \mathrm{H}\right]$ Ultrofilm: Application to multiple benzodiazepine receptors. J. Neurosci. Methods 6 : $59-73$.

Wamsley, J. K., M. S. Lewis, W. S. Young, III, and M. J. Kuhar (1981) Autoradiographic localization of muscarinic cholinergic receptors in rat brainstem. $J$. Neurosci. 1: 176-191.

Yamada, S., M. Isogai, H. Okudaira, and E. Hayashi (1983) Regional adaptation of muscarinic receptors and choline uptake in brain following repeated administration of diisopropylfluorophosphate and atropine. Brain Res. 268: 315-320.

Yamamura, H. I., and S. H. Snyder (1974) Muscarinic cholinergic binding in rat brain. Proc. Natl. Acad. Sci. U. S. A. 71: 1725-1729. 